\title{
Performance evaluation of 50MWp solar plant under different climatic conditions
}

\author{
Mohamed Saleck Heyine ${ }^{1,4}$, Ahmed Mohamed Yahya ${ }^{1}$, Daha Hassan Daher ${ }^{2}$, Léon Gaillard ${ }^{3}$, \\ Christophe Menezo $^{4}$, Abdel Kader Mahmoud ${ }^{1}$ \\ ${ }^{1}$ Département de Physique, Faculté des Sciences et Techniques, Université de Nouakchott Al-Asriya, Nouakchott, Mauritanie \\ ${ }^{2}$ Laboratoire des Energies Nouvelles et Renouvelables, Centre d'Etudes et de Recherche de Djibouti, Djibouti, Djibouti \\ ${ }^{3}$ Heliocity SAS, 31 rue Gustave Eiffel, Grenoble, France \\ ${ }^{4}$ Université Savoie Mont Blanc, Le Bourget-du-Lac, France
}

\begin{abstract}
Article Info
Article history:

Received Jul 22, 2021

Revised Feb 1, 2022

Accepted Feb 8, 2022

Keywords:

Arid climate

Grid-connected

Performance analysis

PV system

Saharan environment

Solar power plant

ABSTRACT

The aim of this study was to evaluate a performance analysis of a $50 \mathrm{MWp}$ solar plant connected to the medium voltage electrical grid installed in the Saharan environment of Nouakchott, Mauritania. This study is done in two seasons characterizing the climate of Nouakchott, then in three typical days based on the measurement data that are obtained from the site of the installation. The measurements were collected daily, to improve the performance evaluation, real-time measurements with a step of 10 seconds for solar irradiation, ambient temperature, module temperature, wind speed, and electrical parameters. The performance evaluation was done based on the IEC 61724 standard to study the comportment of the power plant during different weather conditions. The total energy produced by the plant in May 2020 dry season is $10.559 \mathrm{GWh}$. However, the total energy produced in November 2019 wet season was $8.132 \mathrm{GWh}$. Besides, the energy injected by the plant into the grid was for a clear day $263.87 \mathrm{MWh}$, while for a cloudy day was 118.41 MWh, while it was $39.81 \mathrm{MWh}$ for a sandstorm day. The results showed that temperature and irradiation play an important role in the performance of the system.
\end{abstract}

This is an open access article under the CC BY-SA license.

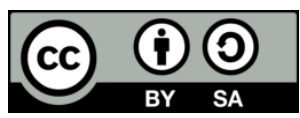

\section{Corresponding Author:}

Mohamed Saleck Heyine

Département de Physique, Faculté des Sciences et Techniques, Université de Nouakchott Al-Asriya

Nouakchott, Mauritanie

Email: med.salek.heyine@ieee.org

\section{INTRODUCTION}

Energy is one of the main pillars for any country aiming to increase its socio-economic and technicalindustrial development. This is why the consumption of electrical energy in the world has been increasing for the last decade. Providing energy without intermittency while ensuring resources for future generations is the ultimate challenge for humanity. In this context, the trend to increase the share of renewable energy power plants in electricity production, which contributes to the respect of the environment by reducing the emission of greenhouse gases from fossil fuels [1], [2]. Several types of power plants are based on renewable energy, such as wind farms, solar photovoltaic plants, and others [2]. Solar photovoltaic power plants are systems for producing electrical energy from the sun's radiation, they occupy a prominent place because of their many special features [3]. Solar PV energy has increased significantly over the past decade, from $23 \mathrm{GW}$ in 2009 to 627 GW in 2019 [4]. Global solar PV capacity additions are expected to reach nearly $107 \mathrm{GW}$ in 2020 [5].

In the era of this trend, many countries are currently re-examining their national energy policies intending to switch to a mix of renewable and conventional energy sources. It is in this perspective; Mauritania 
is oriented to the large-scale integration of renewable energies to achieve a more balanced national energy mix [6]. Thanks to this orientation various projects have seen the light, notably a photovoltaic power plant of 15 MWp connected to the MT network of Nouakchott is put into service since 2013, a wind power plant of 30 MW in Nouakchott is in service since 2014, a photovoltaic power plant of $50 \mathrm{MWp}$ is inaugurated November 2017 in Nouakchott, This plant will be the subject of our study in this paper, a wind power plant of $100 \mathrm{MW}$ is under construction in Boulanouar since 2018, hybrid solar power plants in the interior of the country Kiffa, Atar, Nema, Adel Bagrou, and Aleg provide electrification in these cities since 2017 [7].

Mauritania is one of the aridest Sahelian countries and the most exposed to the effects of desertification, it is located in a geographical axial position between the Sahara and the Sahel. It is characterized by an arid and subtropical climate, constantly hot, dry, and dusty, with a strong influence of the Atlantic Ocean to the west [8]. The Saharan desert space in Mauritania represents $3 / 4$ of its surface, the remaining $1 / 4$ represents the Sahelian zone [9]. The performance and proper functioning of these energy infrastructures that operate in an arid climate is a subject of research that preoccupies the research units in the fields of renewable energy in Mauritania. Some studies have been conducted on the performance evaluation of solar PV plants installed worldwide. We present in the following the most recent studies on the performance of PV systems in several countries with different metrological characteristics.

Several studies have been caried out to analysis performance of solar PV technologies, [10] presented a study that highlights the state of solar energy in Hungary and analysis the performance of a $9.6 \mathrm{kWp}$ solar installation consisting of two different photovoltaic technologies: polycrystalline silicon photovoltaic technology and amorphous silicon mounted on a roof and connected to the grid. The study of this facility is based on one year of data retrieved from January 2016 to December 2017 with a 10 minutes interval, [11] presented a study of the performance of monocrystalline and polycrystalline solar photovoltaic modules, under the climatic conditions of Manizales-Colombia. Both systems are connected to the electrical grid of the city of Manizales, the first one is a polycrystalline system of $2115 \mathrm{Wp}$, and the second one is a monocrystalline system of $2040 \mathrm{Wp}$. Data for this study were collected every 10 minutes for each variable, and the analysis was conducted over four seasons. Zaghba et al. [12] the others examined the impact of seasonal variation and different climatic conditions (sunny, partly cloudy, and cloudy) on the performance of a $2.25 \mathrm{kWp}$ gridconnected PV installation installed on the roof of a parking lot, the installation is based on thin-film silicon technology in the desert environment of the Ghardaïa region, Algeria. The data was recorded with a measurement step of $5 \mathrm{~min}$. The performance evaluation of a grid-connected photovoltaic system of $1.75 \mathrm{kWp}$ based on monocrystalline silicon modules installed in the Saharan zone of southern Algeria (Adrar), in three typical days of the year 2014 under variable climatic conditions (clear, cloudy, and sandstorm) is presented in [12]. Dabou et al. [13] the others examined the impact of seasonal variation and different climatic conditions (sunny, partly cloudy, and cloudy) on the performance of a $2.25 \mathrm{kWp}$ grid-connected PV installation installed on the roof of a parking lot. The measurement data in this study were recorded at an interval of $1 \mathrm{~min}$. Karami et al. [14] presented an experimental study of different silicon-based PV modules (monocrystalline (c-si), Polycrystalline (p-si), and Amorphous (a-si)) during 3 days under varying climatic conditions (clear, cloudy, and rainy).

Real-time measurements were taken every five minutes for different climate parameters. The experimental study was performed to assess the real performance of the selected technologies under real conditions in Casablanca, Morocco. In Ghana the others [15] examined the performance of five solar photovoltaic systems with a total capacity of $20 \mathrm{KWp}$ with five different solar cell technologies such as polycrystalline, monocrystalline, copper indium sulfide thin-film, amorphous silicon, and heterojunction incorporating a thin film under a humid tropical climate in Ghana. Daher et al. [16] the others provided experimental results on the performance of a $300 \mathrm{KWp}$ grid-connected photovoltaic power plant using polycrystalline silicon technology operating in dusty maritime and desert climatic conditions in Djibouti using data for the first 4 years of operation of this plant from February 1, 2012, to December 31, 2015, with a minuteby-minute and hour-by-hour step measurement of the electrical performance and environmental conditions respectively. The characteristics, behavior, and sensitivity of a $6.5 \mathrm{KWp}$ grid-connected PV system under varying environmental parameters under tropical climate conditions in Japan is presented in [17], their photovoltaic system using one-year data from August 2009 to July 2010 for two PV technologies mc-SI and CIS. For a large solar power plant, the others in [18] examined a $10 \mathrm{MWp}$ solar power plant using polycrystalline technology in the Indian climate. This study analyzes and compares the performance results of the plant for one year, from April 2014 to March 2015, with the simulation results of the PVsyst and GIS software. Also in Mauritania, the study presented in [19] provided the evaluation and analysis of the performance of a $15 \mathrm{MWp}$ solar photovoltaic power plant installed in Nouakchott using amorphous silicon and micro amorphous silicon technology, their examination was done by exploiting Scada data for one year from September 2014 to August 2015 with a 5 min step.

The various studies presented below were based on the standard established by the international energy agency (IEA), and described in the standard IEC 61724 [20] for the analysis of the performance of 
different solar photovoltaic installations. The parameters evaluated in the different installations presented above are mainly the energy production, the reference yield, the array yield, the final yield, the capture and system losses, and the PR. However, until now, few researchers have focused on the daily behavior of large grid-connected PV plants to analyze their performance under arid climate with a very small measurement step size and seasonal analysis. The main objective of this work is to analysis the daily performance of the largest grid-connected PV power plant and to appraise the impact of the climatic context in dry and wet seasons, but also in three typical days (clear, cloudy, sandstorm) with a measurement step of ten seconds. The installation was assessed based on various performance parameters, including reference yield, array yield, final yield, system losses, and performance ratio to provide baseline information for the energy evaluation of polycrystalline PV panels. This paper is structured as follows: section 2 describes the PV power plant considered in this work. Section 3 presents the performance analysis methodology. Section 4 presents the results and section 5 summarizes the main conclusions.

\section{DESCRIPTION OF THE SOLAR PHOTOVOLTAIC POWER PLANT}

The Toujounine solar power plant has a capacity of $50 \mathrm{MWp}$ located east of the city of Nouakchott, Mauritania (184'24.532" North, 1552'47.101" West). The photovoltaic plant was commissioned in November 2017. The aerial view of the PV plant is shown in Figure 1 and the schematic diagram of the 50 MWp solar power plant connected to the grid is shown in Figure 2.
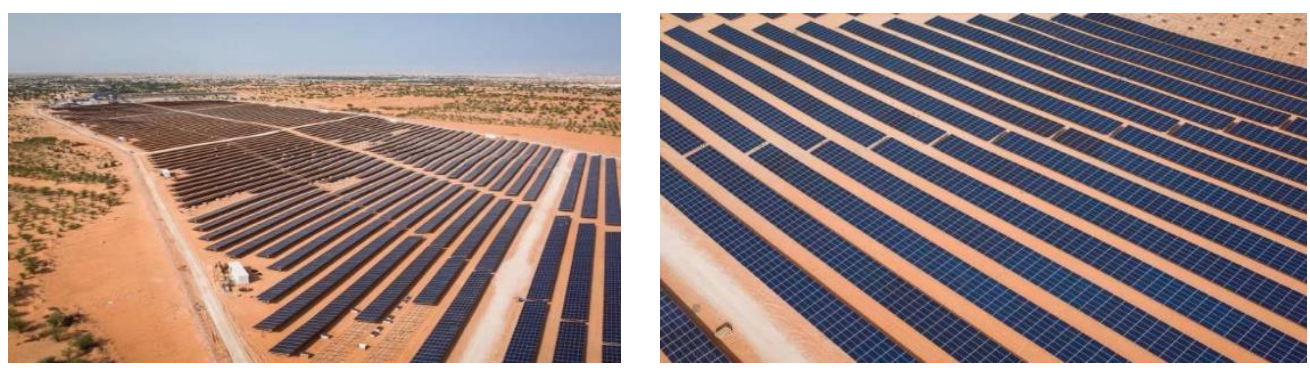

Figure 1. Aerial views of the 50MWp plant, (C) CLEMESSY

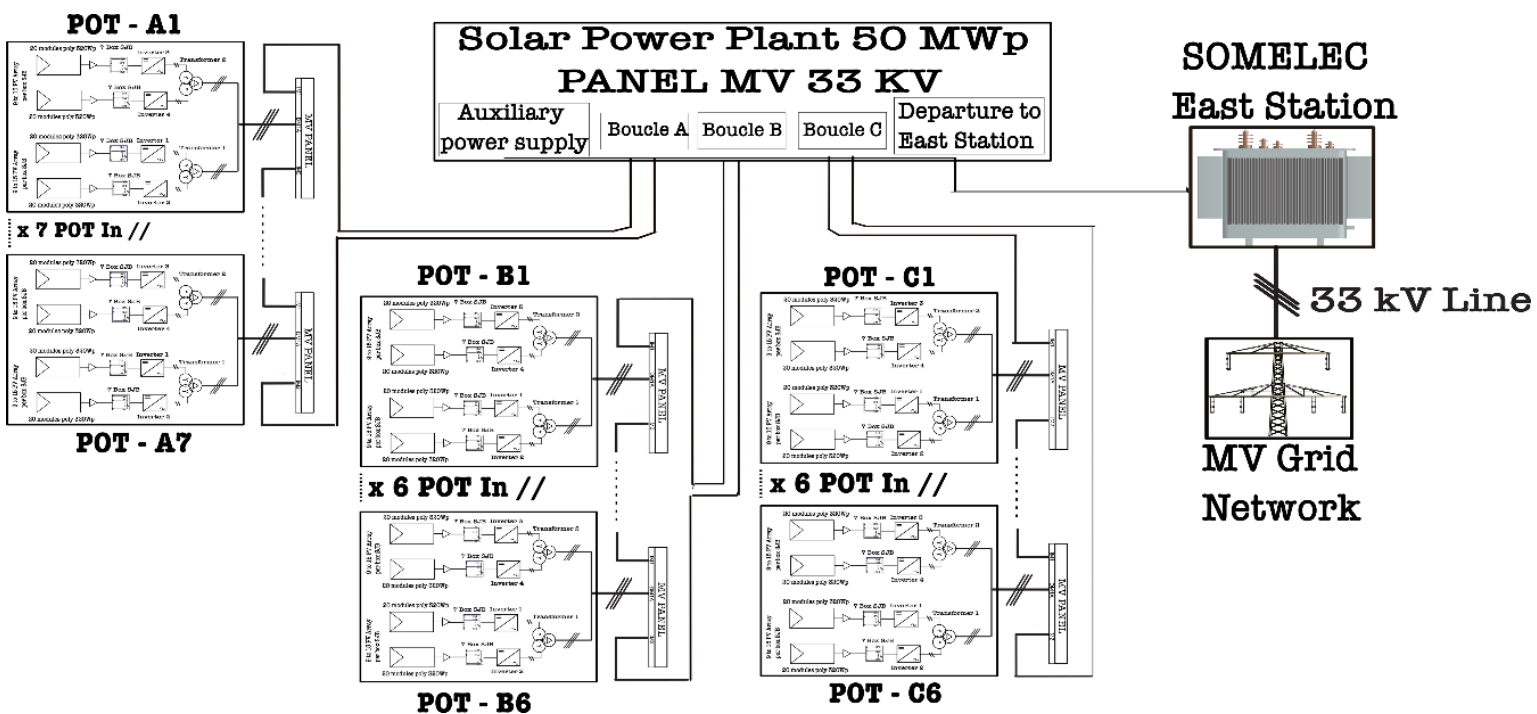

Figure 2. Schematic diagram of the Toujounine power plant

The technology of the modules used in this power plant is the polycrystalline technology, the power plant is composed of 19 chambers each consisting of a post inverter transformer (POT) which are divided into three loops of medium voltage (MT): A, B, and C. Through these loops, the energy produced by the power plant is transmitted to the delivery station. The three loops are distributed as; a) loop A, 7 rooms on which are connected the POT A1 to A7, b) loop B, 6 rooms on which are connected the POT B1 to B6, and c) loop C, 6 rooms on which are connected the POT C1 to C6. This configuration is taken to avoid large losses in case of a 
problem on one of the loops. In the following, we present the technical data and specifications of the components of the solar photovoltaic power plant of Toujounine.

\subsection{PV modules}

The Toujounine solar power plant consists of 156,240 Jinko photovoltaic modules. The modules used are based on polycrystalline technology. The PV modules are oriented to the south and tilted at an angle of $12^{\circ}$. The technical characteristics of the PV modules of this plant are shown in Table 1.

Table 1. PV modules and array specifications

\begin{tabular}{lc}
\hline \multicolumn{1}{c}{ Variable } & Value \\
\hline Solar module type & JKM320PP-72 \\
Maximum power (Pmax) & $320 \mathrm{Wp}$ \\
Power tolerance & $0 \sim+3 \%$ \\
Maximum power voltage (Vmp) & $37.4 \mathrm{~V}$ \\
Maximum power current (Imp) & $8.56 \mathrm{~A}$ \\
Open circuit voltage (Voc) & $46.4 \mathrm{~V}$ \\
Short current circuit (Isc) & $9.05 \mathrm{~A}$ \\
Nominal operating cell temp (NOCT) & $45 \pm 2{ }^{\circ} \mathrm{C}$ \\
Maximum system voltage & $1000 \mathrm{VDC}$ \\
Maximum series fuse rating & $15 \mathrm{~A}$ \\
Operating temperature & $-40{ }^{\circ} \mathrm{C} \sim+85^{\circ} \mathrm{C}$ \\
Faire class & $\mathrm{C}$ \\
Application class & $\mathrm{A}$ \\
Weight & $26.5 \mathrm{Kg}$ \\
Dimension & $21956 \times 992 \times 40(\mathrm{~mm})$ \\
\hline
\end{tabular}

\subsection{Combination boxes}

Combiner boxes are used to join together strings of PV modules into a common output and offer protection to the incoming DC strings in case of a fault, they are used to simplify the wiring of the PV panels in the power plant and offer protection against over-voltage and over-current. In the power plant, there are 532 combination boxes. In each box are connected a maximum of fifteen strings of twenty modules in series as shown in Figure 3. Table 2 shows the technical characteristics of the combination box used in the Toujounine power plant.

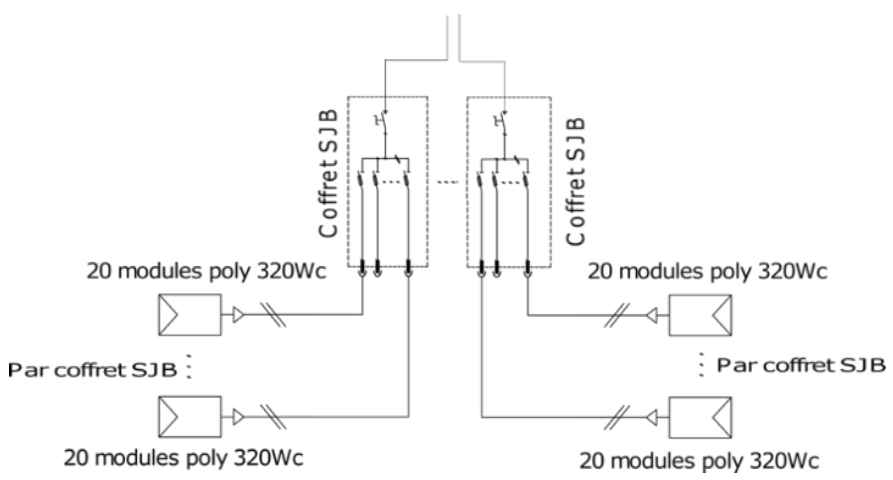

Figure 3. Strings from solar panels

Table 2. Characteristics of the combination box

\begin{tabular}{llc}
\hline & Characteristics & Value \\
\hline DC Inputs ratings & Number of inputs & 10 \\
& Max. voltage in open circuit & $1,000 \mathrm{~V}$ \\
& Max. input current in short circuit & $2,000 \mathrm{~A}$ \\
DC Outputs ratings & Max. voltage in open circuit & $1,000 \mathrm{~V}$ \\
& Max. current in short circuit & $2,000 \mathrm{~A}$ \\
& Max. current in short circuit at STC & $1,600 \mathrm{~A}$ \\
& Max. current in operation & $1,280 \mathrm{~A}$ \\
Auxiliary AC ratings & Related voltage & $230 \mathrm{~V}$ \\
& Related frequency & $50 / 60 \mathrm{~Hz}$ \\
& Over-voltage category & $\mathrm{III}$ \\
\hline
\end{tabular}

Int J Pow Elec \& Dri Syst, Vol. 13, No. 1, March 2022: 561-575 


\subsection{Inverters and transformers}

The solar power plant of Toujounine is composed of 76 DC/AC inverters of type Conext Core XC series 680. The inverters are used to convert the DC power produced by the solar field into an AC power that will be injected into the grid through 38 step-up transformers $400 \mathrm{~V} / 33 \mathrm{kV}$ with unit power of $1,360 \mathrm{KVA}$ each, manufactured by Schneider. The technical characteristics of the inverters used in this plant are presented in Table 3.

Table 3. Characteristics of the inverter

\begin{tabular}{llc}
\hline & \multicolumn{2}{l}{ Conext Core XC series central inverters XC 680 } \\
\hline Input (DC) & Input voltage range MPPT & $550-800 \mathrm{~V}($ at PF $=1)$ \\
& Input voltage range, Operating & $550-800 \mathrm{~V}$ \\
& Max. input voltage, open circuit & $1,000 \mathrm{~V}$ \\
& Max. input current & $1,280 \mathrm{~A}$ \\
& Max. input short circuit current & $2,000 \mathrm{~A}$ \\
Output (AC) & Nominal output power & $680 \mathrm{KVA}$ \\
& Real power & $680 \mathrm{KW}(\mathrm{at} \mathrm{PF}=1)$ \\
& Reactive power range & $+/-680 \mathrm{KVAr}$ \\
& Output voltage & $380 \mathrm{~V}$ \\
& Related frequency & $50 / 60 \mathrm{~Hz}$ \\
& Nominal output current & $1,040 \mathrm{~A}$ \\
& Power factor settable range & 0.8 to 1.0 leading and lagging \\
& Power factor range & 0 to 1 leading and lagging \\
& Harmonic distortion & $3 \%$ at rated power \\
\hline
\end{tabular}

\subsection{Data acquisition system and weather station}

The solar power plant of Toujounine has four weather stations, two on loop A (POT A4 and POT A7), one on loop B (POT B4), and one on loop C (POT C3). Each weather station has an experimental measurement device as shown in Figure 4. Each device is composed of; i) a pyranometer (PYH) on the horizontal plane and a pyranometer (PYP) on the module plane to measure the different values of solar radiation, ii) a thermometer probe (4-wire PT-100) to measure the ambient temperature and the module temperature; and iii) a nanometer (type AIRFLOW TA2), installed at the top of a 2-meter mast, where standard measurements are made to measure wind speed.
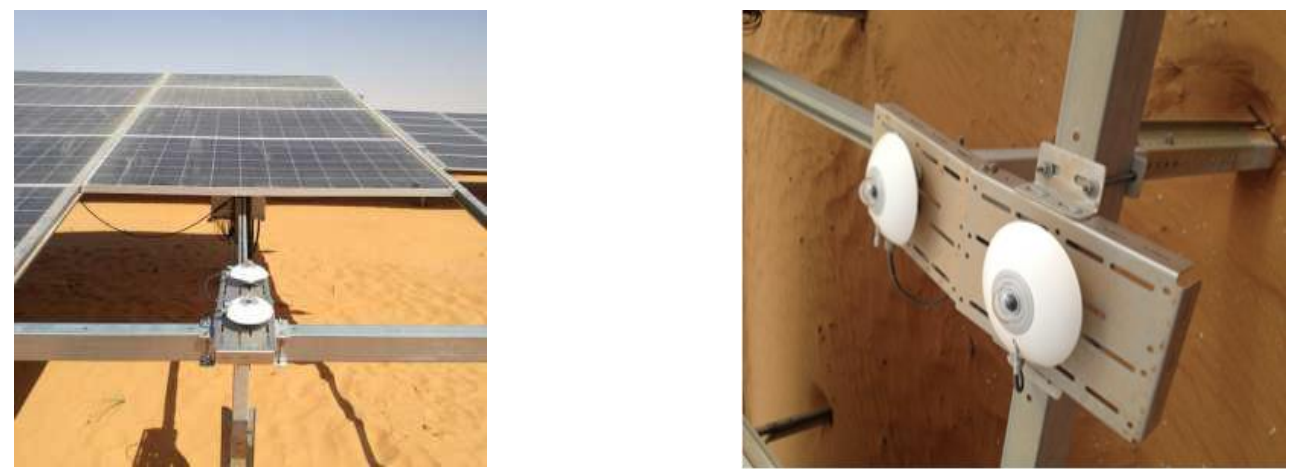

Figure 4. The weather station equipment

\subsection{Monitoring system}

The automatic data acquisition system is required to monitor the performance of a solar installation. The monitoring system is used to control the inverters and communicate the system status and weather data to the user locally or remotely. The solar power plant of Toujounine is controlled by a SCADA system with a storage capacity of $18 \mathrm{~TB}$ that works with the MySQL database and has Siemens Wincc type servers that archive the data of 5,000 variables over 1 year. The SCADA system of the plant provides an interface to all the components of the installation and allows it to process in real-time a large number of parameters and to control the installation remotely. Each POT contains an XM408-8C switch which is connected to the previous POT, the next POT, a thermal camera, an IP phone, and an ET200SP PLC. The PLC is connected to the different measurement stations of the metrological parameters and the measurement counters of the electrical parameters. 


\section{DATA ACQUISITION AND ANALYSIS METHOD}

\subsection{Measurement of metrological parameters}

The performance analysis of this plant is made based on the data recovered from the SCADA for the period from August 1, 2019, to July 31, 2020. The different measurements are collected with a measurement step of 10 seconds. The metrological parameters collected to be used to analyze the performance are sunshine, ambient air temperature, wind speed, and module temperature. The solar power plant of Toujounine has four measuring stations, each POT contains one measuring station in addition to the metrological station which serves as a test bench. The radiation data are measured in the same plane as the photovoltaic field using the pyranometer (PHY and PYP). The temperature of the ambient air is measured with temperature sensors (PT-100) located in solar shields. The temperature of the PV modules is measured with temperature sensors (PT-100) located on the back surface of one module of each measuring station. The wind speed is measured at a height of $2 \mathrm{~m}$ using (AIRFLOW TA2). The location of these sensors in the different weather stations of the installation is representative of the metrological conditions of the plant.

\subsection{Performance analysis methodology}

The International Energy Agency has described in the IEC 611724 standard (IEC-CEI, 1999) [20] the parameters needed to analyze the performance of grid-connected solar PV plants. The performance parameters described by the standard are reference yield, reference PV field, reference system, performance ratio, system losses, and other losses. The performance analysis of photovoltaic system has been the subject of several studies [10], [21] in different countries. The mathematical models of the different performance analysis parameters are presented in Table 4.

Table 4. Performance parameters

\begin{tabular}{lcccc}
\hline \multicolumn{1}{c}{ Parameter } & Mathematical model & Unité & $\mathrm{N}^{\circ}$ Equation & Ref \\
\hline The daily energy produced by PV array (Edc) & $\mathrm{Edc}=\tau \times \sum_{\tau} P p v$ & $\mathrm{MWh}$ & $(1)$ & {$[22],[23]$} \\
The daily energy generated by the system (Eac) & $\mathrm{Eac}=\tau \times \sum_{\tau} P a c$ & $\mathrm{MWh}$ & $(2)$ & {$[22],[23]$} \\
Reference yield (Yr) & $Y r=\frac{G r}{G S T C}$ & $(h / d)$ & $(3)$ & {$[10]-[23]$} \\
Array yield (Ya) & $Y a=\frac{E d c}{P p v}$ & $(h / d)$ & $(4)$ & {$[10]-[23]$} \\
final yield PV (Yf) & $Y f=\frac{E a c}{P p v}$ & $(h / d)$ & $(5)$ & {$[10]-[23]$} \\
Performance ratio (PR) & $P R=\frac{Y f}{Y r}$ & $(\%)$ & $(6)$ & {$[10]-[23]$} \\
Array capture losses $(\mathrm{Lc})$ & $\mathrm{Lc}=\mathrm{Yr}-\mathrm{Ya}$ & $(h / d)$ & $(7)$ & {$[10]-[23]$} \\
System losses $(\mathrm{Ls})$ & $\mathrm{Ls}=\mathrm{Ya}-\mathrm{Yf}$ & $(\%)$ & $(8)$ & {$[10]-[23]$} \\
PV efficiency $\left(\mu_{\mathrm{PV}}\right)$ & $\mu_{\mathrm{PV}}=\frac{E d c \times 100 \%}{G r \times A a}$ & $(\%)$ & $(9)$ & {$[10]-[23]$} \\
System efficiency $\left(\mu_{\mathrm{sys}}\right)$ & $\mu_{\mathrm{sys}}=\frac{E a c \times 100 \%}{G r \times A a}$ & $(\%)$ & $(10)$ & {$[10]-[23]$} \\
Inverter efficiency $\left(\mu_{\text {inv }}\right)$ & $\mu_{\text {inv }}=\frac{E a c \times 100 \%}{E d c}$ & $(\%)$ & $(11)$ & {$[10]-[23]$} \\
\hline
\end{tabular}

Where $(\tau)$ the recording interval 10s, $\left(\mathrm{G}_{\mathrm{r}}\right)$ total in-plane solar irradiation $\mathrm{kWh} / \mathrm{m}^{2},\left(\mathrm{G}_{\mathrm{STC}}\right)$ the module's reference in plan irradiance at the standard test condition $1 \mathrm{~kW} / \mathrm{m}^{2},\left(\mathrm{~A}_{\mathrm{a}}\right)$ Area of $\mathrm{PV}$ array $\mathrm{m}^{2}$.

\section{RESULTS AND DISCUSSION}

\subsection{Meteorological parameters}

Mauritania is characterized by a rainy season from July to October and a dry season characterized by a cool period from November to February and a hot period from March to June [8]. Due to the presence of the ocean and the associated wind patterns, the city of Nouakchott enjoys a relatively mild climate compared to the rest of Mauritania. Metrological parameters such as irradiation, module temperature, ambient air temperature and wind speed were collected with a measurement step of 10 seconds during the period from August 1, 2019 to July 31, 2020. Table 5 shows the monthly average of meteorological parameters. Solar irradiance is one of the main parameters for analyzing the performance of PV modules. The average daily irradiance varies from a minimum of $417.183 \mathrm{~W} / \mathrm{m} 2$ in June 2019 to a maximum of $616.923 \mathrm{~W} / \mathrm{m} 2 \mathrm{in} \mathrm{March}$ 2020. The average daily ambient temperature varies from a minimum of $18.751{ }^{\circ} \mathrm{C}$ in January to a maximum of $29.85{ }^{\circ} \mathrm{C}$ in September. The average daily temperature of the module varies from a minimum of $20.368{ }^{\circ} \mathrm{C}$ in January to a maximum of $35.068^{\circ} \mathrm{C}$ in September. The flow of wind over the PV modules contributes to the decrease in the operating temperature of the modules. Because of the cooling impact on PV modules, higher wind speeds are helpful to their functioning [24]. The monthly variation of the daily average speed presented in Table 5; it varies from a minimum of $2.633 \mathrm{~m} / \mathrm{s}$ in December 2019 to a maximum of $4.242 \mathrm{~m} / \mathrm{s}$ in November 2019. 
Table 5. Monthly average of daily weather parameters (August 2019 - Juley 2020)

\begin{tabular}{ccccc}
\hline Month & Tamb $\left({ }^{\circ} \mathrm{C}\right)$ & $\mathrm{Tmod}\left({ }^{\circ} \mathrm{C}\right)$ & $\mathrm{W}(\mathrm{m} / \mathrm{s})$ & $\mathrm{Gr}(\mathrm{W} / \mathrm{m} 2)$ \\
\hline August 2019 & 27.83 & 33.087 & 3.67 & 516.747 \\
September 2019 & 29.85 & 35.068 & 3.274 & 530.791 \\
October 2019 & 29.34 & 32.914 & 3.044 & 514.852 \\
November 2019 & 26.385 & 31.421 & 4.242 & 527.479 \\
December 2019 & 22.391 & 25.052 & 2.633 & 528.436 \\
January 2020 & 18.751 & 20.368 & 2.919 & 532.958 \\
February 2020 & 25.297 & 27.653 & 3.050 & 522.580 \\
March 2020 & 24.62 & 28.733 & 3.343 & 616.923 \\
April 2020 & 25.77 & 30.112 & 4.033 & 586.262 \\
May 2020 & 28.94 & 34.038 & 2.753 & 553.158 \\
June 2020 & 27.184 & 32.233 & 3.981 & 417.183 \\
July 2020 & 27.919 & 33.272 & 3.957 & 485.050 \\
\hline
\end{tabular}

\subsection{Seasonal analysis of performance parameters}

In order to evaluate the behavior of the $50 \mathrm{MWp}$ power plant in the different metrological conditions of Nouakchott, we will in the following analyze the performance of this power plant in two seasons characterizing the climate of Nouakchott the dry season from March to August and the wet season from September to February. The dry season is characterized by a clear sky with high heat and harmattan, we have selected the month of May 2020 to analyze the plant during this season. The wet season is characterized by cloudy skies and strong winds, it is subdivided into a period of rainy and cool, the month of November 2019 is our choice to analyze the plant in the wet season. The performance analysis of the power plant is done by evaluating the instantaneous parameters that are recorded by the data acquisition system incorporated in the SCADA of the power plant.

Figure 5, Figure 6 (a) and Figure 6 (b) shows respectively the irradiance, ambient temperature, and average daily wind speed for May (dry season) and November (wet season) at Toujounine site of the power plant from sunrise to sunset. Although the data for each month is different, the trend is the same. In other words, the average solar irradiance during November (the wet season) was relatively low compared to May with a lot of fluctuation. However, the wind speed in May was always greater than only in November. While the ambient temperature of November was higher in the majority of days than only in May, it can be seen that the module temperature was always higher than the ambient temperature. In Figure 5 the average daily irradiation at the plant site was about $553.158 \mathrm{~W} / \mathrm{m} 2$ in May, while it was $527.479 \mathrm{~W} / \mathrm{m} 2$ in November. The minimum daily average irradiation recorded on November 20 is $207.252 \mathrm{~W} / \mathrm{m} 2$, while the maximum daily average irradiation was $602.611 \mathrm{~W} / \mathrm{m} 2$ recorded on May 03.

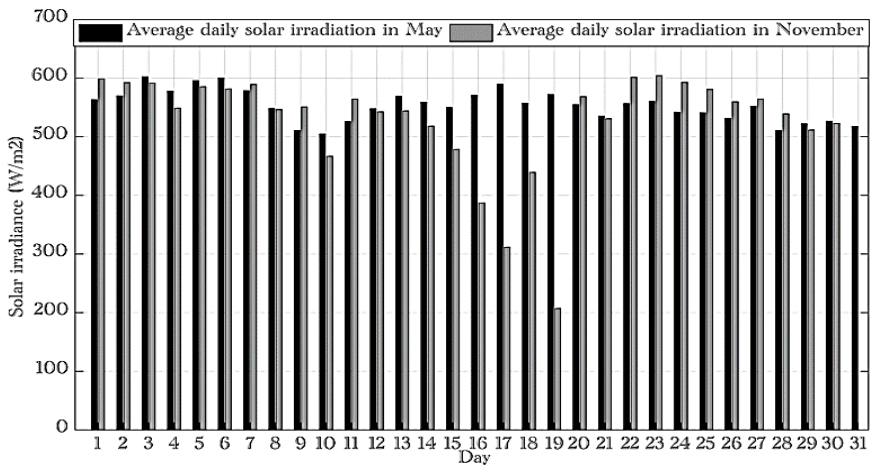

Figure 5. Solar irradiation

In Figure 6 shows the average daily variation of 6 (a) ambiant temperature and 6 (b) wind speed, the daily mean ambient temperature was $28.94{ }^{\circ} \mathrm{C}$ in May, while it was $26.385{ }^{\circ} \mathrm{C}$ for November. The minimum and maximum daily average ambient temperatures are $21.17{ }^{\circ} \mathrm{C}$ and $33.87{ }^{\circ} \mathrm{C}$ recorded on May 11 and November 14 respectively. The average daily value in May is $2.753 \mathrm{~m} / \mathrm{s}$, against $4.242 \mathrm{~m} / \mathrm{s}$ for November. The maximum daily average speed was $5.459 \mathrm{~m} / \mathrm{s}$ recorded on November 08 while the minimum speed recorded on May 15 is $1.837 \mathrm{~m} / \mathrm{s}$. The different seasons have different curves due to the angle of declination of the sun, which results in different times for sunrise and sunset [24]. 


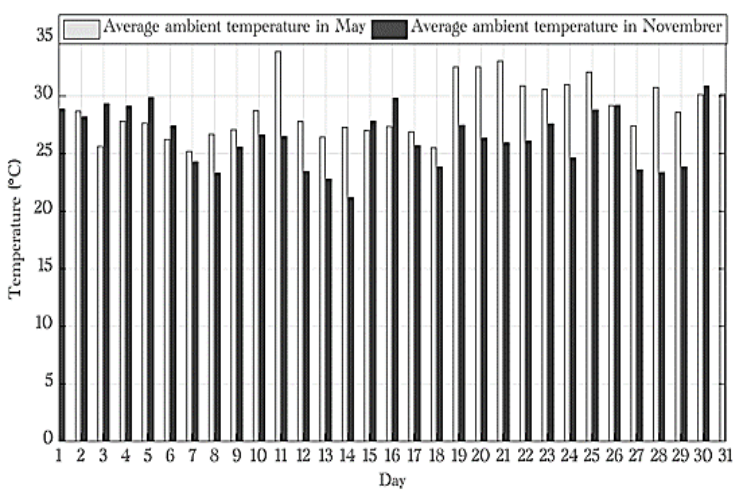

(a)

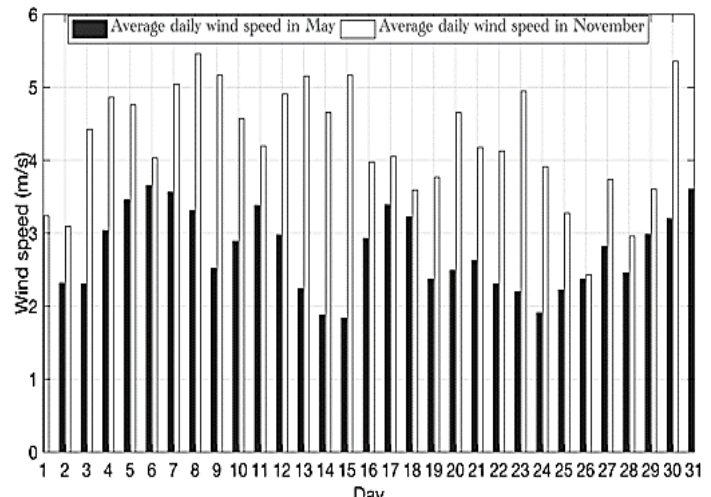

(b)

Figure 6. The average daily variation of (a) ambient temperature and (b) wind speed

The daily average variation of output power is presented in Figure 7 (a) the power delivered by the PV array and Figure 7 (b) the power injected into the grid in May (dry season) and November (wet season). The minimum daily average power of the solar field is $10.27 \mathrm{MWp}$ was recorded on November 19 due to lower solar irradiation and high panel temperature. The maximum daily average power of the solar field was observed during the wet season is $29.94 \mathrm{MWp}$ due to higher solar irradiation and clear sky with low panel temperature. The power injected into the grid varies from $8.52 \mathrm{MW}$ to 21.87 in May, while it varies from $7.91 \mathrm{MW}$ to 23.83 MW in November. The results show that operating temperature of the PV module and the solar irradiation has a significant impact on the performance of the PV module, this affirms the results published in [25].

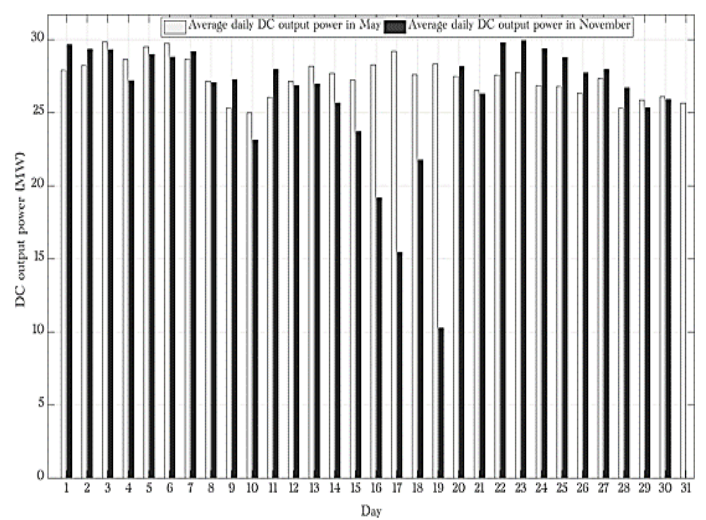

(a)

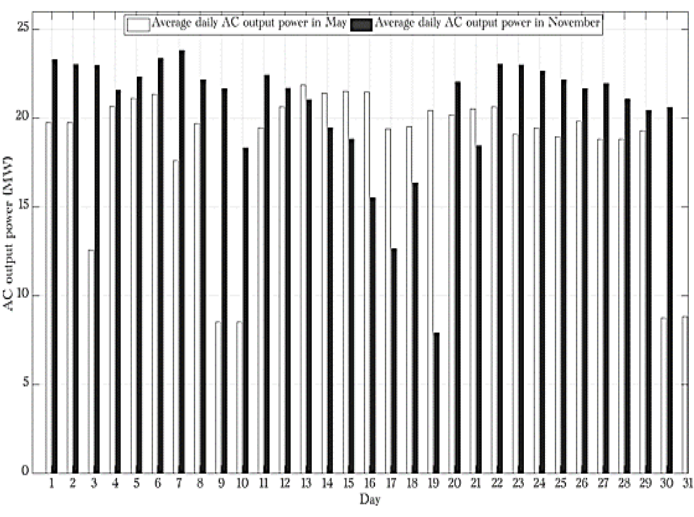

(b)

Figure 7. The average daily variation of (a) DC output power and (b) AC output power

We can observe that the power of the PV field and the power injected into the grid follows the instantaneous changes of the irradiation values in both seasons. It can be seen that for the selected month of the dry and wet season the power reaches its maximum at the same time as the measured solar irradiation, this indicates the accuracy in measuring the solar irradiation. The average daily yield of the reference, final, and system in different seasons (dry and wet) are presented in Figure 8. The average daily yield of minimum reference was observed in November at about $5.87 \%$ and the maximum yield was recorded in May around $7 \%$. The average daily yield of the final minimum in November $5.80 \%$ and the maximum yield is $6.81 \%$ was recorded in May. While the average daily yield of the minimum system is $4.50 \%$ observed in May against a maximum system yield of $4.63 \%$ in November. Table 6 shows the daily average values for reference yield, array yield, final yield, system losses, capture losses, PV efficiency, system efficiency, and inverter efficiency during November 2019 and May 2020, which correspond to the wet season and dry season, respectively. 


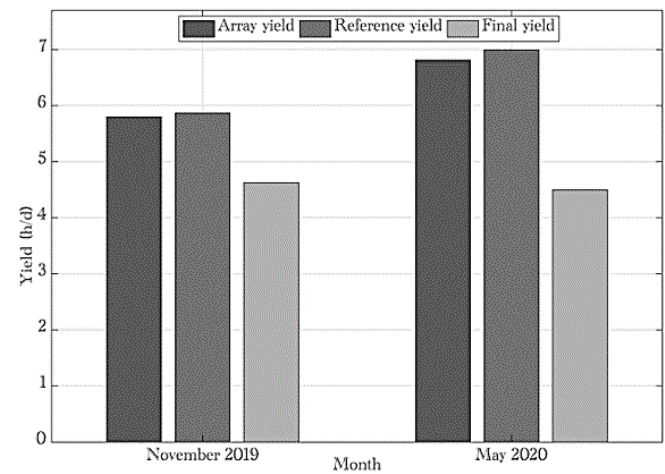

Figure 8. Daily array yield, reference yield, and final yield in different seasons (dry and wet)

Table 6. performance parameters in dry and wet seasons

\begin{tabular}{ccccccccc}
\hline Month & $\mathrm{Y}_{\mathrm{r}}(\mathrm{h} / \mathrm{d})$ & $\mathrm{Y}_{\mathrm{a}}(\mathrm{h} / \mathrm{d})$ & $\mathrm{Y}_{\mathrm{f}}(\mathrm{h} / \mathrm{d})$ & $\mathrm{L}_{\mathrm{s}}(\mathrm{h} / \mathrm{d})$ & $\mathrm{L}_{\mathrm{c}}(\mathrm{h} / \mathrm{d})$ & $\mu_{\mathrm{PV}}(\%)$ & $\mu$ sys $(\%)$ & $\mu \operatorname{inv}(\%)$ \\
\hline May 2020 & 7.00 & 6.81 & 4.50 & 2.31 & 0.19 & 13.78 & 9.07 & 65.84 \\
November 2019 & 5.87 & 5.80 & 4.63 & 1.18 & 0.07 & 14.00 & 11.16 & 79.75 \\
\hline
\end{tabular}

The ratio of the monthly average daily performance of the plant, the monthly average daily energy produced by the solar field, and the energy injected into the SOMELC power grid are presented in Figure 9. The results show that the wet season has a better performance of $78.9 \%$ compared to the dry season of $64.1 \%$ due to a lower ambient temperature, which resulted in a lower panel temperature. It can also be seen that during the dry season the amount of power injected into the grid is greater than in the wet season which is justified by the high demand for electricity often recorded in the dry season in Nouakchott because of the high-temperature rise.

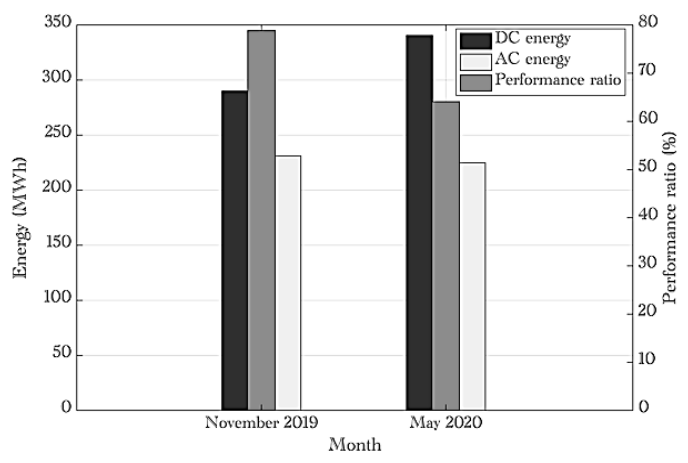

Figure 9. Daily DC energy, AC energy, and performance ratio in different seasons (dry and wet)

\subsection{Daily analysis of performance parameters}

This part consists of analyzing the performance of the $50 \mathrm{MWp}$ solar power plant of Toujounine in three typical days of the year from August 2019 to July 2020 selected from the data recovered from the SCADA system of the plant. The days selected for this study are; i) clear day 03/01/2020, ii) sandstorm day 02/28/2020 and iii) cloudy day 07/06/2020.

Solar irradiance, ambient temperature, module temperature, and wind speed on three typical days (clear, cloudy, and sandstorm) are presented in Figure 10, Figure 11 and Figure 12. Figure 10 shows the daily variation of solar irradiance measured in three days. It can be seen that the clear day is characterized by a higher intensity than the other days with a peak of solar irradiance at about $1 \mathrm{pm}$. Due to the metrological disturbances of the cloud-covered sky and the dust storm, the irradiance in the other two days is characterized by an irregular profile. Figure 11 shows the daily variation of the ambient temperature and the temperature of the modules measured in three days. There is a significant increase in ambient and module temperature for a clear day compared to the other two days. The module temperature is always higher than the ambient temperature. These results are consistent with the results reported in [14], [26]-[28]. 


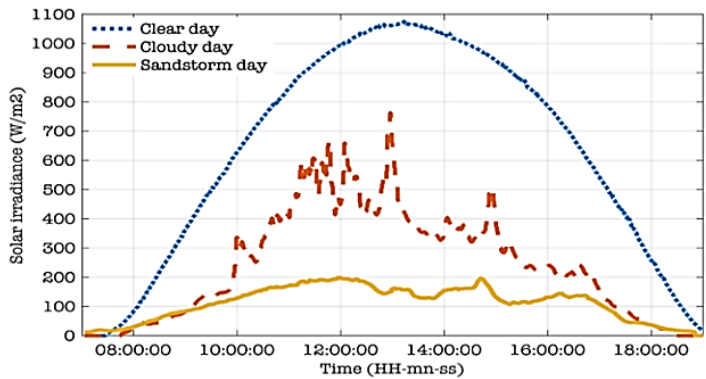

Figure 10. Solar irradiation on different days

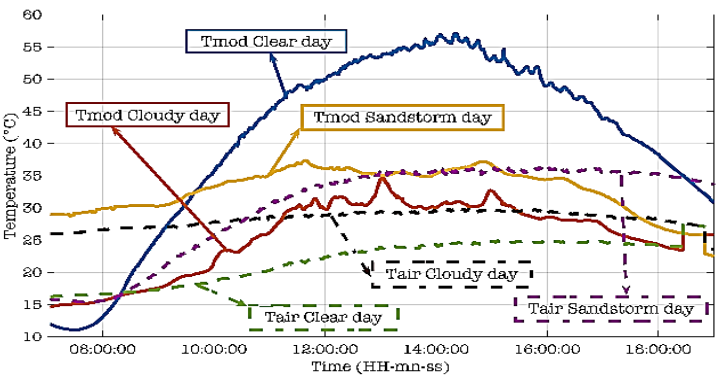

Figure 11. Temperature on different days

As shown in Figure 12 the measured wind speed is more important on a cloudy day than on other days. The difference between the ambient temperature and only the module temperature is more important on a clear day compared to the other two days where the wind speed is more important, this explains the results presented by [12], [13], [29] that the modules cool down quite quickly thanks to the wind speed.

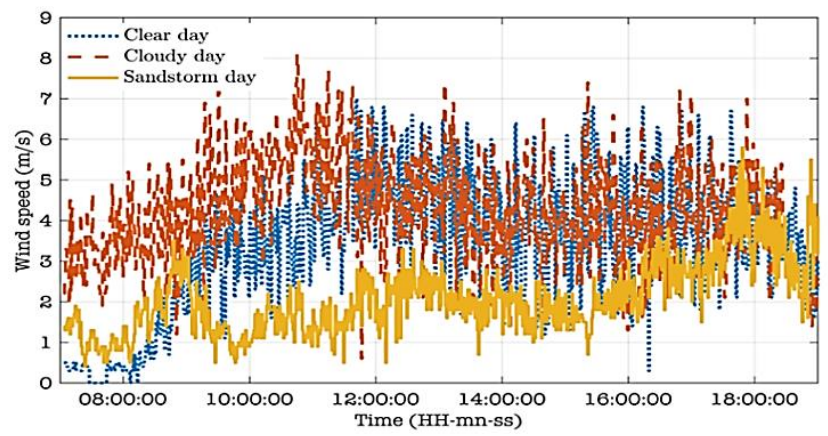

Figure 12. Wind speed on different days (clear, cloudy, and sandstorm)

We can observe that the power of the PV array and the power injected into the grid follows the instantaneous changes of the irradiation values in the three days. It can be seen that for the three selected days the power reaches its maximum at the same time as the measured solar irradiation, this indicates the accuracy in measuring the solar irradiation. The fluctuation of solar radiation on a cloudy day and a sandstorm day caused the fluctuation of the power of the system injected into the grid. The output of the Toujounine solar power plant is better on a clear day than on a sandy or cloudy day. This means that along with module temperature, solar irradiation is a key factor in the production and performance of the PV system. The daily average values of ambient temperature, module temperature, wind speed, solar irradiance, DC output power of the PV array, and the AC output power of the power plant are presented on three typical days (clear, cloudy, and sandstorm) in Table 7.

Table 7. performance parameters in dry and wet seasons

\begin{tabular}{ccccccc}
\hline Day & Tair $\left({ }^{\circ} \mathrm{C}\right)$ & $\mathrm{T}_{\bmod }\left({ }^{\circ} \mathrm{C}\right)$ & $\mathrm{W}(\mathrm{m} / \mathrm{s})$ & $\mathrm{Gr}\left(\mathrm{Kwh} / \mathrm{m}^{2}\right)$ & $\mathrm{P}_{\mathrm{dc}}(\mathrm{MW})$ & $\mathrm{P}_{\mathrm{ac}}(\mathrm{MW})$ \\
\hline Sandstorm Day & 28.35 & 32.92 & 2.04 & 1.33 & 5.61 & 3.15 \\
Clear day & 30.90 & 41.81 & 3.49 & 7.56 & 32.47 & 23.58 \\
Cloudy day & 22.09 & 26.24 & 4.40 & 3.11 & 13.52 & 11.16 \\
\hline
\end{tabular}

The analysis of the grid-connected solar power plant is based on the parameters described by the standard [20] presented in Table 4 of Section 3.2 will be discussed in this section. The daily variation of PV, inverter, and system performance on clear, cloudy, and sandstorm days are presented in Figures 13, 14, and 15, respectively. It is found that the efficiency of the PV module, inverter, and system, is more stable with higher values for a clear day compared to other days, except that the minimum value of efficiency is recorded at the time when the peak irradiation and power are maximum, which can be explained by the fact that the temperature is high. These results affirm the studies [13]-[19], [30], [31] on the effect of temperature on the yield, PV module, inverter, and system. 


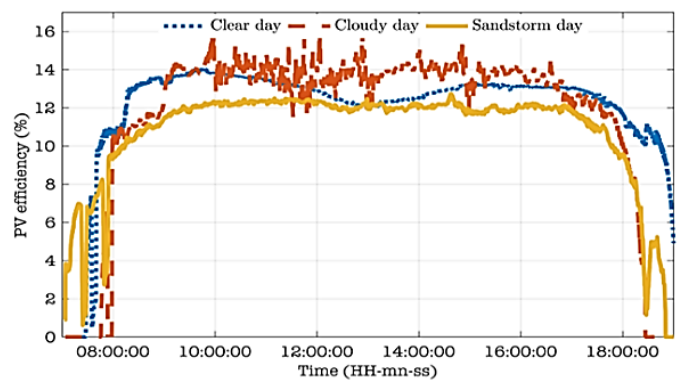

Figure 13. Daily variation of PV efficiency

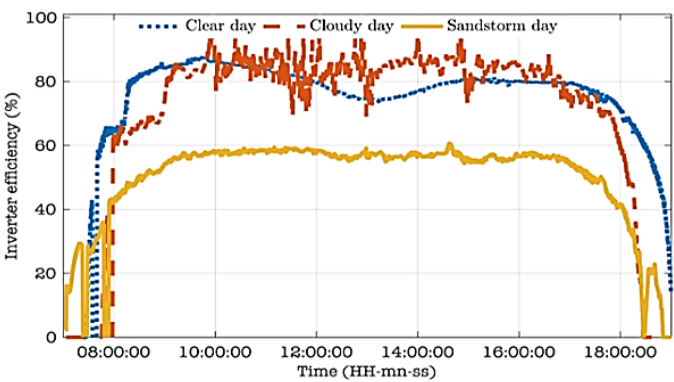

Figure 14. Daily variation of inverter efficiency

In Figures 15, 16, and 17, it can be seen that during the cloudy day, the yield of the PV module, inverter, and system have an irregular variation and with the presence of several peaks, this variation is caused by the rapid succession of irradiation due to the presence of cloud cover. The results also show that on a cloudy day the performance of the PV module, inverter, and system is maximum due to the low temperature and high wind speed that affects the temperature of the module, which is in agreement with the results reported in [13], [29], [30], [32]. The variation in yields and performance ratio is presented in three typical days in Figure 16 and Figure 17 respectively.

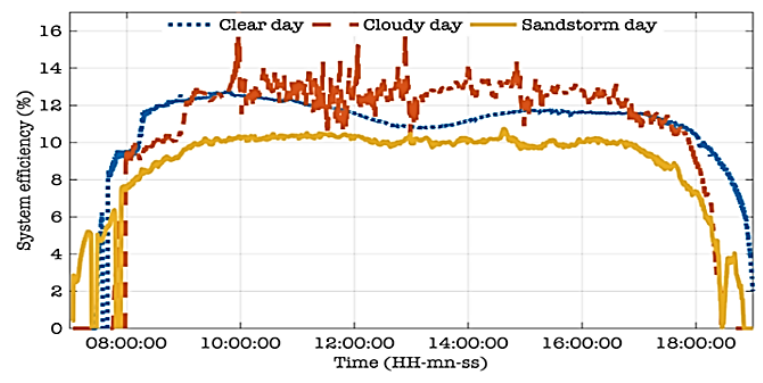

Figure 15. Daily variation of system efficiency

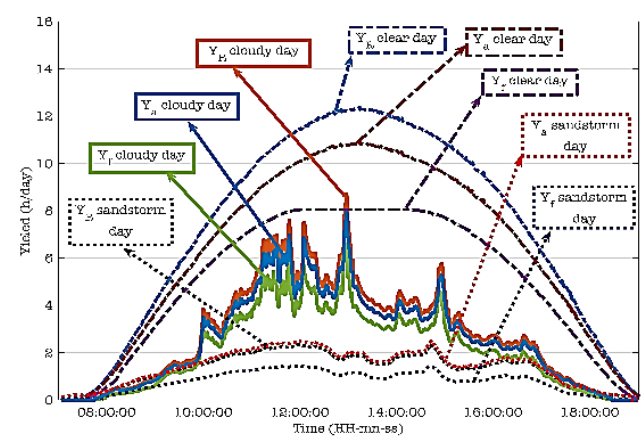

Figure 16. Instantaneous daily variation of array yield, reference yield, and final yield

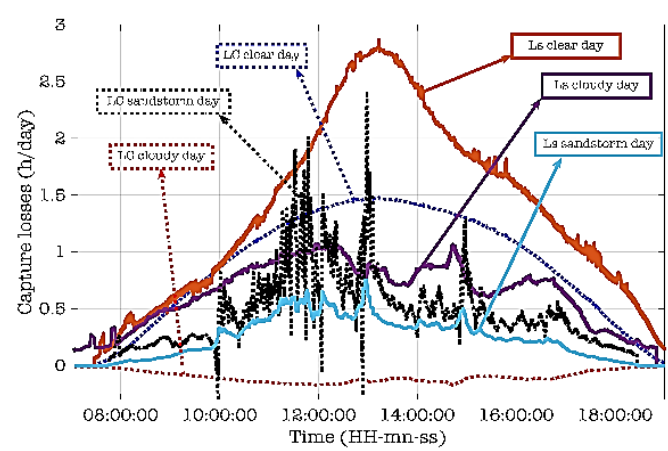

Figure 17. Instantaneous daily variation of capture and system losses

The results presented in Figure 16 and Figure 17 indicate that the average yield, PV array yield, final yield, system, and capture losses for a clear day were $7.56 \mathrm{kWh} / \mathrm{kWp} / \mathrm{day}, 6.66 \mathrm{~kW} \mathrm{h/kWp/day,} 5.28 \mathrm{~kW}$ $\mathrm{h} / \mathrm{kWp} /$ day, $1.38 \mathrm{~h} /$ day, and $0.9 \mathrm{~h} /$ day, respectively, while the average performance ratio for a cloudy day was $73.343 \%$ due to the low wind speed and low ambient temperature. The minimum of array yield, reference yield, final yeild, and system losses during sandstorm day were $1.33 \mathrm{~kW} \mathrm{h/kWp/day,} 1.43 \mathrm{~kW} \mathrm{h/kWp} /$ day and 0.8 $\mathrm{kW} \mathrm{h} / \mathrm{kWp} /$ day and $0.64 \mathrm{~h} /$ day, respectively, while the minimum capture losses were $0.27 \mathrm{~h} /$ day for a cloudy day and the minimum performance ratio was $0.5 \mathrm{~h}$ /day on a clear day due to high ambient temperature. During the sandstorm, the performance ratio was lower than during the cloudy day, due to the low daily solar 


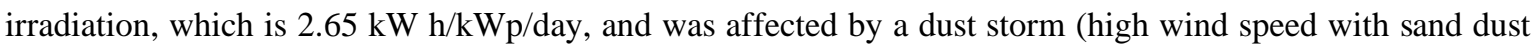
particles) [26], [28].

The Figure 18 shows the average daily yield of the panels, reference, and final in three typical days. Figure 19 shows the average daily losses of the panels and the system during the three typical days. On a clear day, the electrical energy output of the plant is higher than on other days. On a clear day, the percentage of panel collection is high, as well as the system losses, but the output is low due to weather parameters such as increased panel temperature.

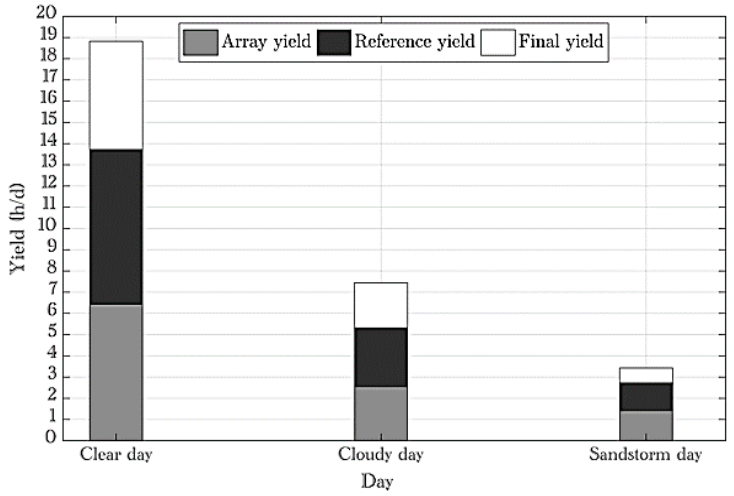

Figure 18. Daily array yield, reference yield, and final yield in different days

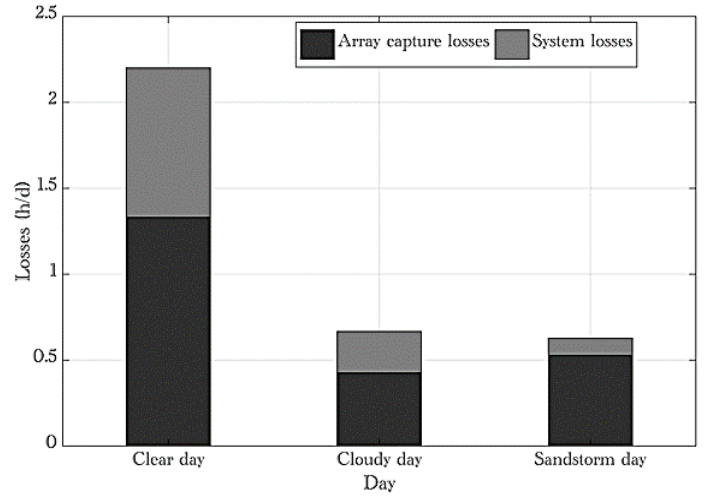

Figure 19. Daily array capture and system losses in different days

The losses of the PV array are higher on clear days than on other days, which shows the effect of module temperature on the performance of the PV array and the performance of the PV system connected to the grid [13], [28], [33]. The Figure 20 shows the daily average variation of the RP, the energy produced by the solar array, and the AC energy injected into the MV grid of Nouakchott on three typical days. The results show that the clear day has a better performance than the other days. It can also be seen that on a clear day, the amount of power injected into the grid is greater than on other days. Table 8 shows the daily average values for array yield, reference yield, final yield, system losses, capture losses, performance ratio, PV efficiency, system efficiency, and inverter efficiency during the monitoring period.

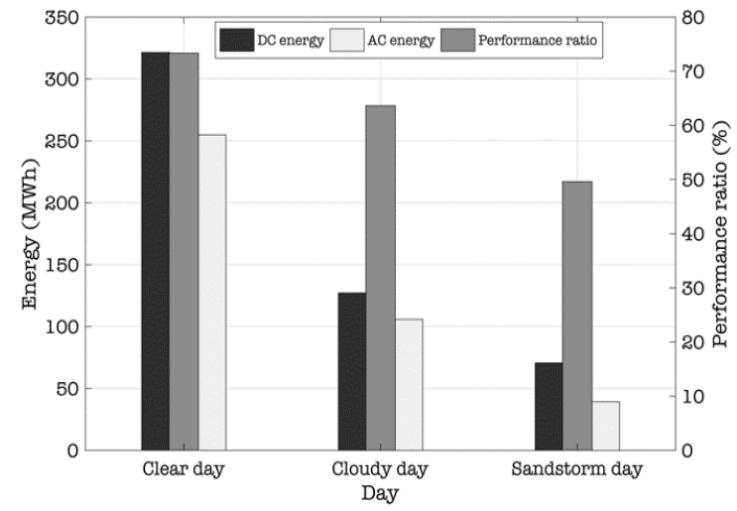

Figure 20. Daily DC energy, AC energy, and performance ratio in different days

Table 8. performance parameters in dry and wet seasons

\begin{tabular}{cccccccccc}
\hline Day & $\mathrm{Y}_{\mathrm{r}}(\mathrm{h} / \mathrm{d})$ & $\mathrm{Y}_{\mathrm{a}}(\mathrm{h} / \mathrm{d})$ & $\mathrm{Y}_{\mathrm{f}}(\mathrm{h} / \mathrm{d})$ & $\mathrm{L}_{\mathrm{s}}(\mathrm{h} / \mathrm{d})$ & $\mathrm{L}_{\mathrm{c}}(\mathrm{h} / \mathrm{d})$ & $\mathrm{PR}(\%)$ & $\mu_{\mathrm{PV}}(\%)$ & $\mu \operatorname{sys}(\%)$ & $\mu \operatorname{inv}(\%)$ \\
\hline Sandstorm Day & 1.33 & 1.43 & 0.80 & 0.64 & -0.10 & 54.02 & 12.71 & 8.91 & 50.30 \\
Clear day & 7.56 & 6.66 & 5.28 & 1.38 & 0.90 & 73.343 & 10.53 & 11.03 & 75.94 \\
Cloudy day & 3.11 & 2.85 & 2.37 & 0.48 & 0.27 & 63.627 & 11.07 & 11.74 & 77.88 \\
\hline
\end{tabular}




\section{CONCLUSION}

This work presented a performance analysis study of the largest grid-connected solar photovoltaic power plant installed in Mauritania with a capacity of $50 \mathrm{MWp}$. The study analyzed the behavior of the plant under the different climatic conditions of Nouakchott. The seasonal analysis in two months (May and November) which reflect the dry season and the wet season characterizing the climate of Nouakchott and the daily analysis in three typical days (clear, cloudy, and sandstorms) allowed us to better understand the effect of the metrological parameters on the operation of the plant. The performance parameters of this plant were analyzed under actual plant operating conditions using one year of data from July 2019 to August 2020 based on measured data with a ten-second measurement step.

In general, the amount of energy injected into the grid, reference yield, PV field yield, final yield, capture losses, system losses received during a clear day are much higher than in cloudy day or sandstorm day. However, we found that the PR is higher on the peak time on a cloudy day than on clear day due to the low average ambient temperature compared to the clear day. This allowed us to conclude that the performance of a grid-connected PV system is influenced by a variety of environmental factors, including ambient temperature, albeit to a lesser extent than solar radiation. In a Saharan climate, the PV system remains an optimal choice due to the amount of solar irradiation recorded, which contributes to improving the energy mix and decreasing the dependence of Saharan countries with arid climates on fossil fuels characterized as expensive. To improve the performance of solar power plants in arid environments, it is recommended to take care of the different modes of degradation of the panels due to the climatic conditions and the accumulation of dust after long exposure to the plant.

\section{ACKNOWLEDGEMENTS}

The authors would like to thank the Ministry of Petroleum and Energy for providing access to data from the 50MWp solar photovoltaic plant in Nouakchott. Some authors have been supported by the French EUR Solar Academy Project (Ref. ANR-18-EURE-0016- Solar Academy).

\section{REFERENCES}

[1] REN21, "Why is renewable energy important?," 2019. [Online] Available: https://www.ren21.net/why-is-renewable-energyimportant/.

[2] International Renewable Energy Agency, "Renewable Energy Policies in a Time of Transition: Heating and Cooling," REN21, 2020. [Online] Available: https://www.irena.org/publications/2020/Nov/Renewable-energy-policies-in-a-time-of-transitionHeating-and-cooling.

[3] K. Kaliappan, M. Sankar, B. Karthikeyan, B. Vineeth, and V. C. Raju, "Analysis of solar energy technology in leading countries," International Journal of Power Electronics and Drive System, vol. 10, no. 4, pp. 1995-2004, 2019, doi: 10.11591/ijpeds.v10.i4.pp1995-2004.

[4] International Renewable Energy Agency, "Renewables Global Status Report," REN21 75015 Paris, [Online] Available: https://www.ren21.net/reports/global-status-report/.

[5] REN21, "Renewables,” Paris, 2020. [Online] Available: https://www.iea.org/reports/renewables-2020.

[6] IRENA, "Renewables Readiness Assessment: Mauritania," 2015. [Online] Available: https://www.irena.org/publications/2015/Sep/Renewables-Readiness-Assessment-Mauritania.

[7] MPEM, "Ministère du Pétrole, de l'Energie et des Mines - Mauritanie," Republique Islamique de Mauritanie, 2015. [Online] Available: http://www.petrole.gov.mr/spip.php?article17.

[8] M. Naia and C. Brito, "Atlas Géographique de la Mauritanie," CIBIO/InBIO. Biodeserts Rapport FR-02. 101, 2021, doi: 10.13140/RG.2.2.16997.42729/1.

[9] A. Gillod, "Nouakchott regional adaptation policies at a glance, "weADAPT, 2019, [Online] Available: https://www.weadapt.org/placemarks/maps/view/60201.

[10] D. Atsu, I. Seres, and I. Farkas, "The state of solar PV and performance analysis of different PV technologies grid-connected installations in Hungary," Renewable and Sustainable Energy Reviews, vol. 141, no. 110808, 2021, doi: 10.1016/j.rser.2021.110808.

[11] L. F. M. Nieto, L. F. E. Cardona, A. M. R. Franco, G. A. G. Gutiérrez, F. N. J. García, and L. M. López, "Energy performance assessment of monocrystalline and polycrystalline photovoltaic modules in the tropical mountain climate: The case for ManizalesColombia," Energy Reports, vol. 6, pp. 2828-2835, 2020, doi: 10.1016/j.egyr.2020.09.036.

[12] L. Zaghba, M. Khennane, A. Fezzani, A. Borni, and I. H. Mahammed, "Experimental outdoor performance evaluation of photovoltaic plant in a Sahara environment (Algerian desert)," International Journal of Ambient Energy, pp. 1-11, 2019, doi: $10.1080 / 01430750.2019 .1636865$.

[13] R. Dabou et al., "Monitoring and performance analysis of grid connected photovoltaic under different climatic conditions in south Algeria," Energy Conversion and Management, vol. 130, pp. 200-206, 2016, doi: 10.1016/j.enconman.2016.10.058.

[14] E. Karami, M. Rafi, A. Haibaoui, A. Ridah, B. Hartiti, and P. Thevenin, "Performance Analysis and Comparison of Different Photovoltaic Modules Technologies under Different Climatic Conditions in Casablanca," Journal of Fundamentals of Renewable Energy and Applications, vol. 7, no. 3, pp. 1-6, 2017, doi: 10.4172/2090-4541.1000231.

[15] D. A. Quansah, M. S. Adaramola, G. K. Appiah, and I. A. Edwin, "Performance analysis of different grid-connected solar photovoltaic (PV) system technologies with combined capacity of $20 \mathrm{~kW}$ located in humid tropical climate," International Journal of Hydrogen Energy, vol. 42, no. 7, pp. 4626-4635, 2017, doi: 10.1016/j.ijhydene.2016.10.119. 
[16] D. H. Daher, L. Gaillard, M. Amara, and C. Ménézo, "Impact of tropical desert maritime climate on the performance of a PV gridconnected power plant,” Renewable Energy, vol. 125, pp. 729-737, 2018, doi: 10.1016/j.renene.2018.03.013.

[17] F. Tahri, A. Tahri, and T. Oozeki, "Performance evaluation of grid-connected photovoltaic systems based on two photovoltaic module technologies under tropical climate conditions," Energy Conversion and Management, vol. 165, pp. 244-252, 2018, doi: 10.1016/j.enconman.2018.03.065.

[18] M. Kumar, S. S. Chandel, and A. Kumar, "Performance analysis of a 10 MWp utility scale grid-connected canal-top photovoltaic power plant under Indian climatic conditions," Energy, vol. 204, no. 117903, 2020, doi: 10.1016/j.energy.2020.117903.

[19] C. E. B. E. Sidi, M. L. Ndiaye, M. E. Bah, A. Mbodji, A. Ndiaye, and P. A. Ndiaye, "Performance analysis of the first large-scale (15 MWp) grid-connected photovoltaic plant in Mauritania," Energy Conversion and Management, vol. 119, pp. 411-421, 2016, doi: 10.1016/j.enconman.2016.04.070.

[20] International Electrotechnical Commission, "Photovoltaic system performance monitoring-Guidelines for measurement, data exchange and analysis," IES 61724, 1998.

[21] T. Adrada Guerra, J. Amador Guerra, B. Orfao Tabernero, and G. de la Cruz García, "Comparative Energy Performance Analysis of Six Primary Photovoltaic Technologies in Madrid (Spain),” energies, vol. 10, no. 6, pp. 1-23, 2017, doi: 10.3390/en10060772.

[22] S. Gulkowski, A. Zdyb, and P. Dragan, "Experimental Efficiency Analysis of a Photovoltaic System with Different Module Technologies under Temperate Climate Conditions,” Applied Sciences, vol. 9, no. 1, pp. 1-13, 2019, doi: 10.3390/app9010141.

[23] M. Adouane, A. Al-Qattan, B. Alabdulrazzaq, and A. Fakhraldeen, "Comparative performance evaluation of different photovoltaic modules technologies under Kuwait harsh climatic conditions," Energy Reports, vol. 6, pp. 2689-2696, 2020, doi: 10.1016/j.egyr.2020.09.034.

[24] A. Bouaichi, A. E. Amrani, M. Ouhadou, A. Lfakir, and C. Messaoudi, "In-situ performance and degradation of three different photovoltaic module technologies installed in arid climate of Morocco," Energy, vol. 190, no. 116368, 2020, doi: 10.1016/j.energy.2019.116368

[25] I. Etier, S. Nijmeh, M. Shdiefat, and O. Al-Obaidy, "Experimentally evaluating electrical outputs of a PV-T system in Jordan," International Journal of Power Electronics and Drive System, vol. 12, no. 1, pp. 421-430, 2021, doi: 10.11591/ijpeds.v12.11.pp421430 .

[26] A. Limmanee et al., "Seasonal variations in performance loss of photovoltaic modules: A case study in Thailand Science Park," Journal of Renewable and Sustainable Energy, vol. 7, no. 5, pp. 1-12, 2015, doi: 10.1063/1.4934677.

[27] A. Maftah and M. Maaroufi, "Experimental evaluation of temperature effect of two different PV Systems Performances under arid climate," Energy Procedia, vol. 157, pp. 701-708, 2019, doi: 10.1016/j.egypro.2018.11.236.

[28] A. L. Mahmood, A. M. Shakir, and B. A. Numan, "Design and performance analysis of stand-alone PV system at Al-Nahrain University, Baghdad, Iraq," International Journal of Power Electronics and Drive System, vol. 11, no. 2, pp. 921-930, 2020, doi: 10.11591/ijpeds.v11.i2.pp921-930.

[29] V. Komoni, A. Gebremedhin, and N. Ibrahimi, "A comparison of the performance of mono-Si and poly-Si photovoltaic modules operating under Kosovo climate condition," Journal of Renewable and Sustainable Energy, vol. 10, no. 1, pp. 1-18, 2018, doi: $10.1063 / 1.5007740$

[30] K. Attari, A. Elyaakoubi, and A. Asselman, "Performance analysis and investigation of a grid-connected photovoltaic installation in Morocco," Energy Reports, vol. 2, pp. 261-266, 2016, doi: 10.1016/j.egyr.2016.10.004.

[31] J.-Y. Wang, Z. Qian, H. Zareipour, and D. Wood, "Performance assessment of photovoltaic modules based on daily energy generation estimation," Energy, vol. 165, pp. 1160-1172, 2018, doi: 10.1016/j.energy.2018.10.047.

[32] L. C. de Lima, L. de Araújo Ferreira, and F. H. B. de Lima Morais, "Performance analysis of a grid connected photovoltaic system in northeastern Brazil," Energy for Sustainable Development, vol. 37, pp. 79-85, 2017, doi: 10.1016/j.esd.2017.01.004.

[33] A. K. Tossa et al., "Energy performance of different silicon photovoltaic technologies under hot and harsh climate," Energy, vol. 103, pp. 261-270, 2016, doi: 10.1016/j.energy.2016.02.133

\section{BIOGRAPHIES OF AUTHORS}

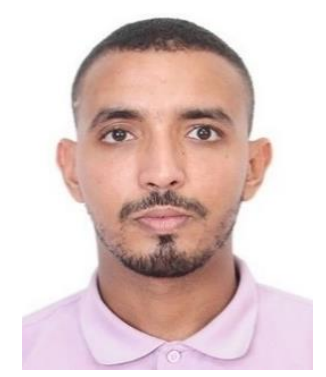

Mohamed Saleck Heyine (D) SC P (IEEE Student Member S'18) was born in Nouakchott, Mauritania in 1991. He received the B.Sc. degree in Electronics Electrotechnical Automation from the Faculty of Science and Technology, Nouakchott, Mauritania, in 2014, and the M.Sc. degree in electrical engineering (Control of Electrical Systems) from the Higher Institute of Industrial Systems, University of Gabes, Tunisia, in 2016. He is currently working toward a Ph.D. degree at the University of Nouakchott Al Aasriya. His research interests include photovoltaics and power electronics, the performance evaluation and analysis of PV systems, and photovoltaic power plant grid-connected. He is affiliated with IEEE as student member and he is involved in NGOs, student associations, and managing non-profit organizations. He can be contacted at email: med.salek.heyine@ieee.org.

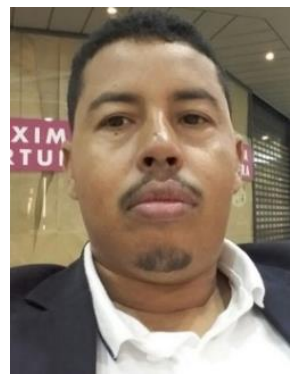

Ahmed Mohamed Yahya (iD 8d SC P was born in Magta-Lehjar, Mauritania, in 1977. He is a lecturer in Physics Department, University of Nouakchott Al-Asriya, Mauritania since 2017. He received his DUEG and Master degree in Electronics, Automatic and Electrical engineering from Nouakchott University, Mauritania, in 2002 and 2003 respectively, in 2005 he got his Diploma of the In-depth Studies in Solar Energy from the University of Cheikh Anta Diop, Dakar, Senegal, and then his PhD degree in Solar energy Materials and Systems of Cheikh Anta Diop, Dakar, Senegal, in 2011. Since 2004, he was a Founder and active member in the Research Center for Renewable Energy (CRAER), Nouakchott, Mauritania. From October 2010 he was nominated as Technical Director of the National Agency for the development of the Renewable Energies in Mauritania (ANADER). He participated in 
several national and international meetings relative to the renewable energies (Campus d'Exelencia 2007, Espagne). He is the author of several publications and technical notes in electrical engineering and in renewable energy fields. He can be contacted at email: biyah2001@yahoo.fr.

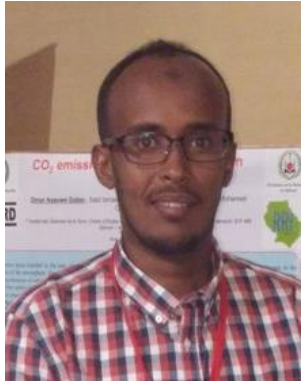

Daha Hassan Daher (D) SC P $\mathrm{P}$ is a researcher and head of the Laboratory of New and Renewable Energies of the Center for Studies and Research of Djibouti (CERD). He holds a $\mathrm{Ph} . \mathrm{D}$ from the National Institute of Applied Sciences in Lyon, France. He works on photovoltaic (PV) performance analysis, PV fault diagnosis and PV modeling. He is a member of the International Solar Energy Society (ISES). He can be contacted at email: daha.enea@gmail.com.

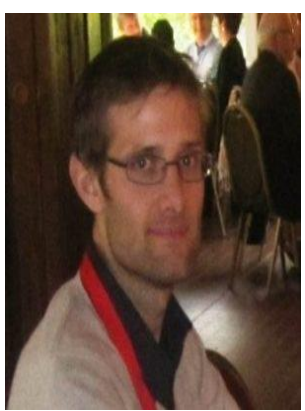

Leon Gaillard (iD I8] SC P is CTO and cofounder of Heliocity, a solar analytics software company based in France that specialises in the remote diagnostic analysis of photovoltaique installations in the built environment. Having received his $\mathrm{PhD}$ in high energy experimental physics at the University of Birmingham in 2008, Leon pursued international development projects in the field of rural electrification in South East Asia, before returning to Europe to undertake solar energy and buildings research in France from 2011. Leon has held positions at the CNRS LOCIE laboratory, National Institute of Solar Energy (INES), and previously at the University of Lyon 1 (UCBL) and INSA-Lyon. Leon is the co-author of academic publications in the field of relativistic heavy ion collisions, solar energy generation, building physics, and decentralised energy technologies. He can be contacted at email: leon.gaillard@heliocity.io.

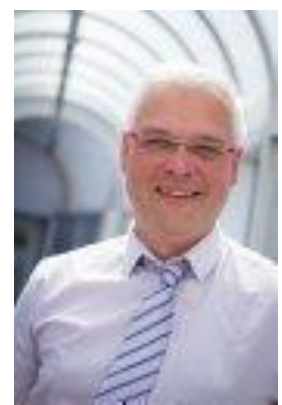

Christophe Ménézo (iD) SC SC P is a Professor Head of the CNRS Research Federation on Solar Energy and Head of LOCIE UMR CNRS/USMB lab (Process, Energy, Building). He is a professor at University Savoie Mont Blanc since 2008 where he teaches in the "Environment-Building-Energy" sector in an engineering school. He is doing his research at LOCIE lab, component of the National Institute of Solar Energy (INES). He is working on the integration of solar components (BIPV/ Hybrid PV/Th) to the frame and the redefinition of the envelope of buildings to include adaptive and active energy functions. Other fields of interest are bio-inspired engineering for energy efficiency and solar power generation in built environment (solar cadaster). He can be contacted at email: chmen@univ-savoie.fr.

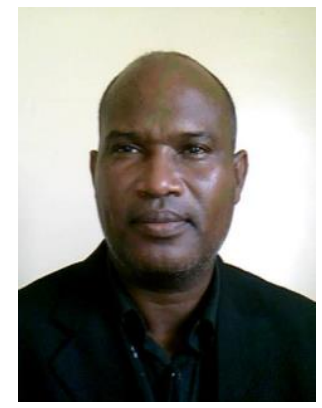

Abdel Kader Mahmoud (D) SI SC P was born in Aleg (Mauritania) in 1960. He received his Master of Sciences degree in power stations in 1988 and his $\mathrm{PhD}$ degree in electrical engineering from the Technical University of Tashkent in Uzbekistan, in 1991. Then, he received his second doctorate of state degree in renewable energy from the University Cheikh Anta Diop, Dakar (Senegal), in 2008. From 1992 until now he works as a Professor at the University of Nouakchott (Mauritania). Currently he is in charge of the Research Center for Renewable Energy. From October 2010 he was nominated as Executive Director of the National Agency for the development of the Renewable Energies in Mauritania. Professor Abdel Kader Mahmoud organized and participated in several national and international meetings relative to the renewable energies. He is the author and co-author of several publications and technical notes in electrical engineering and in renewable energy fields. $\mathrm{He}$ can be contacted at email: nakader@yahoo.fr. 